\title{
The Effect of Intellectual Capital Disclosure on The Performances of Private Universities
}

\author{
Rabiyatul Jasiyah ${ }^{1, *}$, Endang Tri Pratiwi ${ }^{2}$, Suriadi $^{3}$, Refika $^{4}$, Frans Judea Samosir ${ }^{5}$, \\ Muchammad Zaenal Mutatqin ${ }^{6}$ \\ ${ }^{1}$ Universitas Muhammadiyah Buton, Indonesia \\ ${ }^{2}$ Universitas Muhammadiyah Buton, Indonesia \\ ${ }^{3}$ Universitas Muhammadiyah Buton, Indonesia \\ ${ }^{4}$ STAIN Diniyah Pekanbaru, Indonesia \\ ${ }^{5}$ Universitas Prima Indonesia Medan, Indonesia \\ ${ }^{6}$ Universitas Islam Riau Pekanbaru, Indonesia \\ *Corresponding author. Email: rabiyatul.jasiyah@umbuton.ac.id
}

\begin{abstract}
This research aims to find out the influence of intellectual capital disclosure, such as human resources, structural capital and relational capital on the performance of private universities. The analysis units in the study were 149 private universities, determined by purposive sampling. Data analysis uses logistic regression as one of the multivariate data analysis techniques. The findings show that human capital, structural capital and relational capital have a simultaneous effect on the performance of private universities.
\end{abstract}

Keywords: Human Capital, Structural Capital, Relational Capital, Performance of Private Universities.

\section{INTRODUCTION}

In managing a university, intellectual capital has an important role in producing intellectual human resources [1]. Human resources are a benchmark used in the evaluation, assessment of quality qualifications, performance and the quantity of human resources who participate in implementation of programs at universities that concern education, research and community service.

The Education Sector, especially university [2] explain that intellectual capital is an intangible asset of the institution and including patents, copyrights, procedures, change capabilities, public acceptance, education and their abilities, skills, and communication networks. Colleges are required to manage intangible assets and stimulate universities to report their intellectual capital to the public properly [3] [4] [5]. Intellectual capital highlights 3 main components such as human capital, structural capital and relational capital[1] [6] [7].
The number in Sulawesi of universities reaches hundreds. The dominant college is the private college. Private colleges compete for market positions, they must be more strategic by identifying their resources and creating organizational strategies that meet the demands of various stakeholders [4] [8]. In addition, a competitive environment forces private universities to manage and operate their activities in different ways. A college cannot access strategic objectives simply by having the ability to manage and evaluate the performance of its colleges. Quality services are services based on intellectual quality standards so as to improve the performance of private universities [9]. Elements of intellectual capital cannot be achieved unless the organization has good and sophisticated methods for assessing its performance and maintaining it, with changes taking place in the competitive environment.

Based on these problems, motivating to empirically test intellectual capital so that college performance increases, and this is in accordance with the view of experts that intellectual capital is difficult to understand, 
but once found and exploited can provide new resources to compete and trade for a company [10].

\section{LITERATURE REVIEW}

As a form of accountability for the existence of a social contract between the company and the surrounding community, legitimacy theory serves to encourages companies to make voluntary disclosures [11]. This theory of legitimacy when characterized by the level of intellectual capital disclosure, it can be said that companies whose legitimacy is still questioned can use the information disclosed in public disclosure to improve their legitimacy in the eyes of the public. Base on [12] stated that all stakeholders have the right to know about company activities that affect them. According to stakeholder theory, company management must be able to carry out activities that are considered important to stakeholders and report back on these activities to stakeholders in order to specifically maintain integrity.

Based on [13] intellectual capital can create wealth by utilizing intellectual material (intellectual property, information, knowledge, and experience). Resource in which the organization depends not only on human resource capital but also the organization itself and its relationship to the environment is the definition of intellectual capital [14] [15]. Intellectual capital is a combination of human resources, organization, and organizational relationships. Disclosure of information about intellectual capital is one of the ways to increase the value of a company, where information about intellectual capital is presented to the university is a tool that covers the entire process of knowledge production in the university environment.

Based on [7] [16] identifying three elements of intellectual capital, including human capital, structural capital, and relational capital. Human capital is the organization's most valuable asset, including employee knowledge, experience and skills. Structural capital supports human capital. This Including patents, copyrights, procedures, rules and policies, procedures and trademarks. An organization's relationship with stakeholders inside and outside the organization is the relational capital of an organization. Human capital brings innovation and renewal in a company both through brainstorming, reengineering and intelligence among members of the organization [10] [17]. We can see that structural capital consists of mechanisms that enable employees to achieve optimal performance, as they may have the right systems and processes to achieve performance. Structural capital is the most significant investment in the university. Correlation capital is the most important component of intellectual capital for college performance.

The research is studied according to theoretical thinking and empirical facts from several previous research studies, thus making the above construct a research statement explaining as a determinant of factors in the performance of the private university.

\section{RESEARCH METHOD}

This research is an explanatory study, which aims to analyse the impact of disclosure of intellectual capital information on efficiency private universities in Sulawesi, using quantitative approaches through parameter testing in answering hypotheses. Data collection to answer website-based hypotheses. The population in this study is all private universities in Sulawesi. The sample was selected by the method of targeted sampling, so that a sample of 149 private universities in was obtained in accordance with the following criteria: Private universities in Sulawesi, private universities whose accreditation is recorded in National Accreditation agency for Higher Education (BAN-PT). Thus, obtained private universities in Sulawesi consist of 112 well-performing universities that perform well or excellent.

The Intellectual Capital framework used for the university consists of 36 items developed [18] which is a modification of [6] and the university accreditation provisions set by the National Accreditation agency for Higher Education (BAN-PT).

Measuring intellectual capital disclosure is using index numbers. The disclosure index for each private college corresponding to the sample is obtained in the following ways: Providing a score for each disclosure item, where the disclosed item is assigned a value of one, and if not disclosed is given a value of zero. The scores obtained by each private college are summarized to get the total score. Divide the total score obtained by the total score expected by the college to calculate the disclosure completeness index. The performance measure used in this study is accreditation. If the college has accreditation is rated 1 and 0 if the item is not disclosed. The analytical method used in this study used logistic regression analysis with SPSS software.

\section{RESULTS AND DISCUSSION}

Testing the suitability or feasibility of data on the sample size of the study, as well as on a number of research indicators that meet the eligibility index requirements seen in Table 1 . Which shows the sig value. Hosmer and Lemeshow Test is $1,000>0.05$ then it can be concluded that the model formed according to the observation data ( $\mathrm{H} 0$ received), so that the logistic regression model is suitable for use at a later stage, as shown in table 1. 
Table 1. Hosmer and Lemeshow Test

\begin{tabular}{|l|r|l|l|}
\hline Step & Chi-square & df & Sig. \\
\hline 1 & .000 & 7 & 1.000 \\
\hline
\end{tabular}

Sources: Results of research data processing, 2021

The evaluation of the overall model is indicated by the block number -2 log-likelihood (-2LL) step 0 and -2 log-likelihood (-2 LL) step 1 in the data analysis results. A decreases in -2LL at step 0 (167.024) and -2LL step 1 (15.777) of the analysis results showed a better regression. This step aims to test the suitability between the model and the data, as shown in table 2.

Table 2. Overall Model Fit

Iteration History a,b,c

\begin{tabular}{|rl|r|r|}
\hline \multicolumn{1}{|l|}{ Iteration } & -2 Log likelihood & \multicolumn{1}{l|}{ Coefficients } \\
\cline { 3 - 4 } & & & \multicolumn{2}{l|}{ Constant } \\
\hline \multirow{3}{*}{ Step 0 } & 2 & 167.312 & -1.007 \\
& 3 & 167.024 & -1.105 \\
& 4 & 167.024 & -1.108 \\
& 4 & 167.024 & -1.108 \\
\hline
\end{tabular}

Sources: Result of research data processing, 2021

The model assessment test aims to find out how much a dependent variable can be explained by a variable independent by looking at the value of Cox and Snell's R Square. The output in Cox and Snell's R square of 0.638 in table 3 showed that the effective contribution given by variables human capital, structural capital and capital relationships with the performance of private universities was $63.8 \%$.

Table 3. Coefficient of Determination

\section{Model Summary}

\begin{tabular}{|l|l|l|l|}
\hline Step & $\begin{array}{l}-2 \text { Log } \\
\text { likelihood }\end{array}$ & $\begin{array}{l}\text { Cox \& Snell R } \\
\text { Square }\end{array}$ & $\begin{array}{l}\text { Nagelkerke R } \\
\text { Square }\end{array}$ \\
\hline 1 & $15.777 \mathrm{a}$ & .638 & .946 \\
\hline
\end{tabular}

Sources: Results of research data processing, 2021

Check the simultaneous effect of the independent variable on the dependent variable. The results of the simultaneous test are shown in the table 4

Table 4. Simultaneous Test Results

Omnibus Tests of Model Coefficients

\begin{tabular}{|rl|l|l|l|}
\hline & & $\begin{array}{l}\text { Chi- } \\
\text { square }\end{array}$ & df & Sig. \\
\hline Step 1 & Step & 151.247 & 3 & .000 \\
& Block & 151.247 & 3 & \\
\hline
\end{tabular}

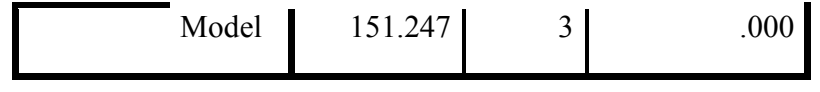

Sources: Results of research data processing, 2021

The findings of this study showed the Chi-Square model value was 151,247 with a significant value of 0.000 . A significant value of $0,000>0.05$ indicates that human capital variables, structure capital, and relationship capital simultaneously effect the performance of private universities.

\section{CONCLUSION}

The results showed that intellectual capital, that is, human capital, structural capital and relationship capital, simultaneously affects the performance of private universities, so we can say that intellectual capital is a combination of human resources, organizations and organizational relationships. Other findings from this study show that these three components are a single unit that supports each other in a private university. The university's performance in this case the accreditation of private universities in Sulawesi will be better if supported by professional human capital which is balanced with structural capital support and builds strong partnerships in both academic and non-academic aspects. The implication of this study is that intellectual capital is an asset that must be managed appropriately so that the performance of private universities in Sulawesi in this case its accreditation can be further improved.

\section{AUTHORS' CONTRIBUTIONS}

All authors have contributed in developing the research including providing financial assistance for publication needs. Author 1 develops idea in the form of formulations or overall development goals, for research purposes. The second writer processes the data and analyses the data, the third writer is in charge of management and coordination affairs for research planning and implementation, the fourth writer carries oyt research data collection and plagiarism testing, the writer translation into English, and the writer carries out the preparation, and verification of reproducible result of conduct able research.

\section{ACKNOWLEDGMENTS}

We would like to thank to the Association of KODELN (Collaboration of Lecturers Across Countries) in Indonesia for the support and contribution to this review article so it can be accepted in the International Conference on Social, Economics, Business, and Education (ICSEBE 2021) organized by the University Makassar State (UNM).

\section{REFERENCES}

[1] W. M. Lu, "Intellectual capital and university 
performance in Taiwan," Econ. Model., vol. 29, no. 4, pp. 1081-1089, 2012, doi: 10.1016/j.econmod.2012.03.021.

[2] Y. Ramírez and S. Gordillo, "Recognition and measurement of intellectual capital in Spanish universities," J. Intellect. Cap., vol. 15, no. 1, pp. 173-188, 2014, doi: 10.1108/JIC-05-20130058 .

[3] C. Leandro and P. Sánchez, M., "Intellectual Capital Management and Reporting in Universities and Research Institutions Redalyc Sistema de Información Científica Intellectual Capital Management and Reporting in Universities and Research Institutions Asociación de Economía Aplicada Españ," no. July 2014, 2008.

[4] A. Bakhsha, A. Afrazeh, and A. Esfahanipour, "Identifying the variables of intellectual capital and its dimensions with the approach of structural equations in the educational technology of Iran," Eurasia J. Math. Sci. Technol. Educ., vol. 14, no. 5, pp. 1663-1682, 2018, doi: 10.29333/EJMSTE/85037.

[5] Kateřina Kuralová and K. Margarisová, "Intellectual Capital Disclosure At Czech Public Universities in Relation," vol. 64, no. 6, pp. 1989-1998, 2016.

[6] Y. R. Córcoles, J. F. S. Peñalver, and Á. T. Ponce, "Intellectual capital in Spanish public universities: Stakeholders' information needs," J. Intellect. Cap., vol. 12, no. 3, pp. 356-376, 2011, doi: 10.1108/14691931111154689.

[7] I. Ulum, A. Tenrisumpala, and E. D. Wahyuni, "Intellectual Capital Disclosure: Studi Komparasi Antara Universitas Di Indonesia Dan Malaysia," Akuntabilitas, vol. 9, no. 1, pp. 1326, 2016, doi: 10.15408/akt.v9i1.3582.

[8] C. J. K. Abdullah N. A. Alkhateeb1, Liu Yao2, "INTELLECTUAL CAPITAL PRACTICES' IN UNIVERSITIES," Int. J. Accounting, Financ. Bus. Int. J. Accounting, Financ. Bus. Int. J. Accounting, Financ. Bus. Int. J. Accounting, Financ. Bus. Int. J. o, vol. 3, no. 13, pp. 19-25, 2018.

[9] Suriadi et al., "The consciousness of excellent quality service to improve effectiveness of TQM and kaizen-PDCA quality management," IOP Conf. Ser. Earth Environ. Sci., vol. 343, no. 1, 2019, doi: 10.1088/1755-1315/343/1/012138.

[10] B. Nick, "Mapping the human capital management research trends using bibliometric analysis," Manag. Decis., vol. 32, no. 6, pp. 6376, 1998.

[11] J. Guthrie, R. Petty, K. Yongvanich, and F. Ricceri, "Using content analysis as a research method to inquire into intellectual capital reporting," J. Intellect. Cap., vol. 5, no. 2, pp. 282-293, 2004, doi: 10.1108/14691930410533704.

[12] Y. An, H. Davey, and I. R. C. Eggleton, "Towards a comprehensive theoretical framework for voluntary IC disclosure," $J$. Intellect. Cap., vol. 12, no. 4, pp. 571-585, 2011, doi: 10.1108/14691931111181733.

[13] A. Schneider and G. Samkin, "Intellectual capital reporting by the New Zealand local government sector," J. Intellect. Cap., vol. 9, no. 3, pp. 456-486, 2008, doi: $10.1108 / 14691930810892036$.

[14] K. H. Leitner, "Intellectual capital reporting for universities: Conceptual background and application for Austrian universities," Res. Eval., vol. 13, no. 2, pp. 129-140, 2004, doi: $10.3152 / 147154404781776464$.

[15] Nuryaman, “The Influence of Intellectual Capital on The Firm's Value with The Financial Performance as Intervening Variable," Procedia - Soc. Behav. Sci., vol. 211, no. January, pp. 292-298, 2015, doi: 10.1016/j.sbspro.2015.11.037.

[16] U. Shehzad, Z. Fareed, B. Zulfiqar, F. Shahzad, and H. S. Latif, "The Impact of Intellectual Capital on the Performance of Universities," Eur. J. Contemp. Educ., vol. 10, no. 4, pp. 273280, 2014, doi: 10.13187/ejced.2014.10.273.

[17] P. Nikolaj Bukh, C. Nielsen, P. Gormsen, and J. Mouritsen, "Disclosure of information on intellectual capital in Danish IPO prospectuses," Accounting, Audit. Account. J., vol. 18, no. 6, pp. 713-732, 2005, doi: $10.1108 / 09513570510627685$.

[18] F. Anggraini, M. A. Abdul-Hamid, and M. K. A. Azlina, "The role of intellectual capital on public universities performance in Indonesia," Pertanika J. Soc. Sci. Humanit., vol. 26, no. 4, pp. 2453-2472, 2018. 